\title{
EUPHEMISM - AS A LINGUISTIC UNIT EXPRESSING NATIONAL-MENTAL IDENTITY
}

\author{
Raupova L.R.
}

D.Sc, Professor Of The Department "Linguodidactics", Tashkent State University Of Uzbek Language And Literature Named After A.Navai, Uzbekistan

Safarova G.Q.

Senior Teacher, Department Of "Linguodidactics", Tashkent State University Of Uzbek Language And Literature Named After A.Navoi, Uzbekistan

\section{ABSTRACT}

The article deals with the euphemic use of language units, which are one of the social features of the language, euphemic phenomena, the commonality of language and culture between them. It is noted that the study of the connection of language units with the context, the situation of speech only gives a full opportunity to correctly understand their meaning, which determines the need for sociolinguistic knowledge. It is noted that the cultural similarity of euphemisms stems from the uniformity of the tasks assigned to them. It is concluded that the use of euphemisms in speech often depends on the values that have developed in a particular society, the norms of etiquette and socio-cultural speech norms.

KEYWORDS: - Sociolinguistic studies, National mental factors, sociopragmatic studies, ethnolinguistics, ethnopsychology, cognitive psychology, psycholinguistics, sociolinguistics and social linguistics

\section{INTRODUCTION}

In the current globalisation process, the integration of science and education, the relationship between various sciences as well as the boundary between them, acquires a rather relative character. Therefore, among all scientific directions in linguistics "...the task of comprehensive support of scientific and creative research, creation of the necessary conditions for them" 1 indicates the need to conduct in-depth

\footnotetext{
${ }^{1}$ Мирзиёев Ш.М. Эркин ва фаровон, демократик Ўзбекистон давлатини биргаликда барпо этамиз. Ўзбекистон Республикаси Президенти лавозимига
}

research on the integration of sciences. Attention to the state language in our country has increased to the level of the priority. Therefore, along with increasing the effectiveness of preserving, enriching and practically using our native language, special attention is paid to further increase the status of the state language and practically use linguistic opportunities of World linguistics whilst the application of language units in speech and revealing the features of meaning and function shows the necessity of this problem. 
CURRENT RESEARCH JOURNAL OF PHILOLOGICAL SCIENCES 2(10): 125-

133, October 2021

DOI: https://doi.org/10.37547/philological-crjps-02-10-23

ISSN 2767-3758

(C)2021 Master Journals

Crossref do

gil Google

Accepted26 ${ }^{\text {th }}$ October, 2021 \& Published $31^{\text {th }}$ October, 2021

\section{THE MAIN FINDINGS AND RESULTS}

The sociological aspect of the study of the language sector has long been of great interest to linguists. After all, language development, the changes in it are directly related to the development of society. In scientific sources, which existed until the beginning of the XX century, in the connection of linguistics with other sciences, the concepts related to sociolinguistics are described. The dictionary of linguistic terms states: "Sociolinguistics (lot. soci(etas) - society+linguistics) is a branch of linguistics studying the conditions of social existence and social development. This field, consisting of the synthesis of sociology and Linguistics, deals with such problems as the connection of social life with language; active processes in the development of language under the influence of non-linguistic factors; the change in the ratio between the verbal and written form of language with the wide spread of radio, television, cinema etc., the tasks and forms of maintaining language. According to the analysis of scientific literature, sociolinguistics refers to the ability to present the national characteristics of autistic speech, including the social and cultural competence: knowledge of the customs, values, rituals and other national and cultural characteristics of the country, as well as the ability to compare the language with the country that is being studied. That is, to be able to choose discourse in a suitable communicative situation; to understand the essence of the problem that has arisen and the person providing the service of consent when necessary explaining to the customer; being able to choose language forms and applying or changing it in accordance with the professional text within the framework of communicative situations on the topic; being able to communicate in a natural, usual manner for them, which does not arouse admiration or bitterness to the native speakers. As noted above, the development of Sociolinguistics, which appeared at the intersection point of sociology and Linguistics studies, depends on the extent to which the fields are studied, of course. In scientific sources, the forms of sociolinguistic communication are classified as follows: in the process of education, in the family environment; in social groups; in residential, temporary community; in educational institutions, in the production community; in the broad masses of the people, in the public; in nationality, ethnic group; international, between ethnic groups; between citizens divided by age categories; in person; in everyday household life. One of the peculiarities of the language is the euphemist application of language units. Euphemist events reflect the commonality of language and culture in itself. They are inextricably linked with the emergence and growth of national-cultural characteristics of peoples.

The issues of euphemism, its classification and its occurrence in speech have been extensively studied in Russian and European linguistics. In the XX-XXI centuries, a number of scientific studies on the problem of euphemistic lexical and its connection with other language phenomena arose. In particular, euphemism from a historical point of view was considered on the basis of ancient taboos and was analyzed on the basis of materials of Indo-European and Slavic-Baltic languages (L.A.Bulakhovsky, B.A.Larin, E.A.Reformatsky). In the last decades, scientists from Moscow, Petersburg, and Volgograd were engaged in the study of the means and goals of euphemism in the Russian language (L.P.Krisin, V.P.Maskvin, V.Z.Sannikov, E.P.Senichkina). Among the works in this regard, L.A.Bulakhovsky, A.A.Reformatsky, B.A.Larin2

\footnotetext{
2 Ларин Б.А.Об эвфемизмах // Учен. зап. Ленингр. унта,Сер.фил. наук: Вып.№ 60-Л.: ЛГУ,1961.- Р. 110-124.
} 
CURRENT RESEARCH JOURNAL OF PHILOLOGICAL SCIENCES 2(10): 125-

133, October 2021

DOI: https://doi.org/10.37547/philological-crjps-02-10-23

ISSN 2767-3758

(C2021 Master Journals

Crossref do

8 Google

Accepted $26^{\text {th }}$ October, 2021 \& Published $31^{\text {th }}$ October, 2021

studied euphemisms from a historical point of view on the basis of ancient taboos. With the description of the means and goals of euphemism in the Russian language, L.P.Krisin, V.P.Maskvin, V.Z.Sannikov, and E.P.Senichki3 were engaged. A.M.Katsev, N.T.Boschaeva, N.L.Saakayan, Y.S.Baskova and E.O.Miloenko4 dissertations, A.In vildanova's thesis “Эвфемия и принцип вежливости в современном английском языке: гендерный аспект" comprehensively highlight the aspects of English gender euphemisms in English and Russian5. Whereas N.Baskakov revealed the problems of euphemistic nominations in the languages of the Altai people6. So, in Russian linguistics, the subject circle of euphemism is grouped as follows:

\footnotetext{
${ }^{3}$ Крысин Л.П. Эвфемизмы в современной русской речи // www/ Philology.ru; Москвин В.П. Эвфемизмы в лексической системе современного русского языка // Василий Павлович Москвин. 2е изд. - М.: Ленинград, 2007. - 264 с.; Сеничкина, Е.П. Эвфемизмы русского языка. - Москва: Высшая школа, 2006. - 151 с.

4 Кацев А.М. Эвфемизмы в современном английском языке. - Ленинград: Наука, 1977. - 65 с. // Босчаева Н.Ц. Контекстуальная эвфемия в современном английском языке. - Ленинград: Наука, Ленинградское отд., 1989. 130 с. // Саакаян Н.Л. Эвфемия как прагмалингвистическая категория в дискурсивной практике непрямого речевого убеждения: автореф. дисс. ...канд. филол. наук. - Москва, 2010. - 23 с. // Баскова Ю.С. Эвфемизмы как средство манипулирования в языке СМИ (на материале русского и английского языков): дисс. ... канд. филол. наук. - Краснодар, 2006. - 26 с. // Милоенко Е.О. Специфика функционирования эвфемизмов в индивидуальном лексиконе: дисс. ...канд. филол. наук. - Курск, 2009. - 24 с.

5 Вильданова Г.А. Эвфемия и принцип вежливости в современном английском языке: гендерный аспект. Москва-Берлин: Директ-Медиа, 2015. -162 с.

${ }^{6}$ БаскаковН.А.Пережитки табу и тотемизма в языках народов Алтая// Советская тюркология.-Баку.1975. 3-7.
}

1) Expressing some physiological process and condition (expect a child-pregnant);

2) Representing certain parts of the human body;

3) Signifying a sexual relationship;

4) Signaling illness and death (French death colloquial, feeling bad - sick);

5) Representing diplomatic concepts.

L.P.Krisin correctly noted that in the communicative relations of diplomats and politicians there were euphemisms due to the need of use of cynical, directly naming words within the framework of the label.

6)representing some professional corn. It is used for the purpose of increasing the prestige of the profession. For example, a milkman is an operator of a milking machine, a sweeper is an operator of cleaning work.

In Uzbek linguistics N.Ismatullaev and A.Omonturdiyev conducted the scientific work on a special study of the phenomenon of euphemism, their stylistic features, linguistic peculiarities of the euphemisms used in the speech of the breeder ${ }^{7}$. A.Omonturdiev studied

7 Исматуллаев Н.Эвфемизмы в современном
узбекском
языке:автореф.дисс.канд.филол.наукТашк, 1963.

24c.//ОмонтурдиевА.Эвфемик воситаларнинг

функционал-услубий

хусусиятлари:филол.фан.номз.дисс.

автореф.-Т.1997.-23б.//ОмонтурдиевА.Профессионал нутқ эвфемикаси(чорвадорлар нутқи мисолида): филол.фан.докт.дисс.-Т.2009.252б.

${ }^{8}$ ОмонтурдиевА,Омонтурдиев Ж.Сўз кўллаш санъати.-Термиз:

Жайхун,1994.-6б.;ОмонтурдиевА.Бир сўз луғати.Термиз:Жайхун,1996.-45б.;Омонтурдиев А.Ўзбек тилининг қисқача эвфемик луғати.-Тош,2000.- 
CURRENT RESEARCH JOURNAL OF PHILOLOGICAL SCIENCES 2(10): 125-

133, October 2021

DOI: https://doi.org/10.37547/philological-crjps-02-10-23

ISSN 2767-3758

(C2021 Master Journals

sonem

8 Google

Accepted $26^{\text {th }}$ October, 2021 \& Published $31^{\text {th }}$ October, 2021

euphemisms in a wide range as an object of research in stylistics and studied the euphemistic of Uzbek speech in his monographs titled "Euphemisms of Uzbek speech", "Euphemisms of Professional speech", as well as other works such as "One word's dictionary", "The art of word application", "Brief euphemisms of Uzbek language". A.Mamatov, L.Raupova, Z.Kholmanova, X.Kadirova and D.Rustamova's scientific work of the influence of euphemist and dysphemistic units on the formation of phraseology, gender characteristics of euphemisms, author's euphemisms and metaphorical features of euphemisms used in the work "Boburnoma" were analyzed". Also, the phenomenon of euphemism was explained in parts dedicated to the speech methodologies of the handbooks related to the subject ${ }^{9}$. In the textbook "Basics of speech culture and

134б;Омонтурдиев А.Ўзбек нутқининг эвфемик асослари.

-Тошк:Халк мероси,2000.-128б.;Омонтурдиев

А.Профессионал нутқ эвфемикаси.-

Тошк:Фан,2006.232б.

${ }^{8}$ Маматов А.Ўзбек тили фразеологияси шаклланиши масалалари:филол.фанлари д-ри..дисс.автореф.Тошкент, 1999.-56б.//Холманова 3.“Бобурнома” лексикаси тадқиқи:филол.фанлари д-ри..дисс.автореф.Тошкент,2009.-22б.//Қодирова Х.Абдулла Қодирийнинг эвфемизм ва дисфемизмлардан фойдаланиш махорати:филол.фан.номз.дисс.автореф.-

Тошкент,2009.-23б.//Рустамова Д.Метафорик эвфемизациянинг лингвокультурологик ва социопрагматик аспектлари:филол.фан.номз. дисс. автореф. - Фарғона, 2018. - 50 б.

${ }^{9}$ Кўнғуров Р., Бегматов Э., Тожиев Э. Нутқ маданияти ва услубият асослари. - Т.: Ўқитувчи, 1992. - 160 б.; Содиқов А., Абдуазизов А., Ирискулов М. Тилшуносликка кириш. -Т.: Ўқитувчи, 1981. - 266 б.; Mirtojiyev M. O‘zbek tili semasiologiyasi. - Toshkent: Mumtoz so'z, 2010. - 127 b. methodology" and in the textbook "Uzbek language Stylistics" published in $1983^{10}$, some general reference on euphemism and cocophemism (dysphemism) was given.

Linguist M.Mirtojiev's monograph "Semasiology of the Uzbek language" also has a special place in the study of euphemisms. In his monograph, the scientist pays special attention to the issues of the attitude to the phenomenon of taboo and the history of the study of euphemisms. The scientist points out that the euphemist meaning is a derivative, and that this derivative occurs in a metaphorical, metonymical way, and is of great importance in the formation of euphemist meaning from them, especially metaphors. For example, the lexical meaning of the word scorpion was embodied with the word donkey. Because the scorpion's tail is like an ass in terms of its beak. This similarity is the reason for the formation of an euphemistic metaphorical meaning in the word donkey.

H.Shamsiddinov described euphemisms as a phenomenon that causes functional-semantic synonyms. Through euphemisms, people's spirit, worldview, socio-cultural relations are reflected. It embodies the national values, ethics and aesthetic views of the people. As euphemism expresses the concept associated with human life, lifestyle, physical-biological properties, ethics of interactions.

The Researcher N.Gaybullaeva in a number of articles gives special importance to the improvement of the effectiveness of the use of euphemisms in the speech of a doctor, thinking about medical euphemisms. She points out that

\footnotetext{
${ }^{10}$ Шомақсудов А., Расулов И., Кўнғуров Р., Рустамов Х. Ўзбек тили стилистикаси. -Тошкент: Ўқитувчи, 1983. 248 б. Ш.Гулямова. Ўзбек тили эвфемизмларининг гендер хусусиятлари : филол. фан. номз. ... дисс. автореф. - Бухоро, 2020. - 63 б.
} 
CURRENT RESEARCH JOURNAL OF PHILOLOGICAL SCIENCES 2(10): 125-

133, October 2021

DOI: https://doi.org/10.37547/philological-crjps-02-10-23

ISSN 2767-3758

(C)2021 Master Journals

sonere

8 Google

Accepted $26^{\text {th }}$ October, 2021 \& Published $31^{\text {th }}$ October, 2021

euphemizing is the result of linguistic speech, the linguistic aspect of the language of the medical field, the culture of the doctor's communication, the medical deontology, the relationship between the doctor and the patient, the relationship between the doctor and the patient's relatives, the relationship of the doctor with colleagues, medical ethics, the role of psychotherapy in doctor's career.

Researcher Sh.Gulyamova noted in her research that gender is a social norm that studies social gender, human behavior in society, it is a social norm that studies the female and male aspects, sometimes gender can also be used as a synonym for the concepts of "man" and "woman", as well as that it is a clear standard of the behavior of representatives of the two sexes and that euphemisms are gender classified in Uzbek language. Euphemisms in the process of language and culture communication are a common phenomenon. 11

It seems that the study of euphemist units, acquaintance with the work of specialists who classified them, is a significant thematic

\footnotetext{
${ }^{11}$ Mirtojiyev M.M. O‘zbek tili semasiologiyasi. - Toshkent: "Mumtoz so'z, 2010. - В. 119-127. . //Маматов А.Э. Ўзбек тили фразеологизмларининг шаклланиши масалалари: Филол. Фанлари д-ри... дисс. - Тошкент, 1999. - Б.156159. // Шамсиддинов Х. Ўзбек тилида сўзларнинг функционал- семантик синонимлари: Филол.фанлари дри... дисс. автореф. - Тошкент, 1999. - 52 б. . // Shamsiddinov H. So'zlarning evfemik funksional-semantik sinonimlari // O`zbek tili va adabiyoti. -1997.№6.-B.22-25. // Gaybullayeva N.I. The usage of euphemisms in the speech of doctors// International journal of research in humanities, Arts and literature (IMPACT:IJHAL), 2018. - P.525-532. IMPACT Factor. 3.7943. // Ш.Гулямова. Ўзбек тили эвфемизмларининг гендер хусусиятлари. Филология фанлари бўйича фалсафа доктори (PhD) илмий даражасини олиш учун ёзилган диссертация. Бухоро 2020.145 б
}

classification of aspects. In particular, R.Holder's classification is worth the attention. It divides lexical-semantic euphemisms into 60 subclasses. This classification is evidenced by the variety of denotative content of euphemisms. In addition, A.M.Katsev divides euphemisms into 10 thematic groups. In it, there is also a classification according to the ontological character of the more euphemist agent. Social classification holds a special place in the opening of the essence of euphemisms. It is made on the basis of the belonging of the word to a certain social group. Including, B.A.Larin classification can be cited.

Linguistic classification of euphemisms was also carried out by some researchers. From Uzbek linguists N.Ismatullaev divides euphemisms into 5 large groups. These are taboo-related euphemisms, superstitions, euphemisms related to heredity, euphemisms applied in place of words and phrases whose meaning is rude, inconvenient to say, jargon euphemisms used for uplifting and religious purposes, stylistic euphemisms. And the classification of expressions allocated to such groups is called is reflected in the scientific work studied by A.Omonturdiev. The classification of dysphemism was carried out only in a few research works in the field of linguistics. For example, dysphemism in English is classified lexically-semantically as follows: dysphemism that denote death, illness, physical and spiritual defects; dysphemism associated with a wide range of criminal groups; dysphemism associated with human defects; dysphemism that names belonging to the nation; dysphemism associated with God, the devil (Satan), church rituals. Cultural similarities in the euphemisms of different peoples arise from the uniformity of the tasks assigned to them.

Euphemisms can be divided according to their functions: taboo expressive euphemisms and tactful expressive euphemisms. When the 
CURRENT RESEARCH JOURNAL OF PHILOLOGICAL SCIENCES 2(10): 125-

133, October 2021

DOI: https://doi.org/10.37547/philological-crjps-02-10-23

ISSN 2767-3758

(C)2021 Master Journals

sonem

8 Google

Accepted26 ${ }^{\text {th }}$ October, 2021 \& Published $31^{\text {th }}$ October, 2021

existing word is loaded with a euphemistic meaning, this meaning will be the hand-held meaning of the word. That is, it is considered to belong to the lexical level. They associate it mainly with taboos. Direct euphemism is used in place of the word or phrase encountered in the taboo, that is, the meaning of the lexical unit encountered in the taboo is loaded into a particular word, it remains an euphemistic meaning ${ }^{12}$. Since the level of social production was low during the primitive community system, people lack scientific and cultural knowledge. Therefore, they believed in various superstitions, thought that asking directly from God or spirits would bring misfortune. As a result, the name of God and spirits became taboos, and they began to be called slugs with a different name. For example, in Western countries, since the name "Jehovah" of God was considered the greatest taboo in the times when Christianity developed, instead of it, euphemisms such as "mighty", "creator", "savior", "our father" were used. Or in ancient China it was forbidden to be called by the name of emperors. Euphemism is an important part of the philological sphere, and the ability to skillfully use euphemisms in speech is the main sign of having speech abilities. Therefore, great attention is paid to the study of euphemisms. Consequently, a number of achievements have been made in the philological research on euphemisms. But despite this, euphemisms are a complex phenomenon of language. "First of all, euphemisms are a universal phenomenon in this language and speech. From a historical point of view, euphemisms have appeared in the early periods of human civilization, so we can say that they have a long history" ${ }^{13}$.

${ }^{12}$ Usmanova Sh.R. Tarjimaning lingvomadaniy aspektlari. Darslik. - Toshkent: - 2017. - 255 b.

${ }^{13}$ Пшеничникова А.Б.Гендерные спецификации вежливости в директивных речевых актах в
Sociolinguistic aspect of euphemisms in world linguistics has been researched by M.Bauman, B.Kuper, J.Xyuz, X.Roson, F.Bekvit; in Russian linguistics S.G.Ter-Minasova, V.I.Jelvis, A.A.Reformatsky, L.G.Lozine, L.P.Krisin ${ }^{14}$. Euphemism is a unit of language that manifests national-mental originality. The comparison of the lexical-semantic fields, in which the euphemism of languages is actively formed, shows the difference in the taboo system, the reflections on ethics and decency, linguistic originality in the linguistic landscape of the nation. Each language has its own unique style of expression. The unit of language, which requires spelling in Uzbek, may not need such an expression in another language, let's say, in Russian. Among the units that reflect national originality in the Uzbek language, there are such units that even in translation dictionaries there is no alternative. They are distinguished by their linguistic significance. The use of the phraseeuphemism in speech instead of "dunyoga keltirmoq -to give birth", the appearance of the phrase "tug'moq - to give birth" in place of "bo'yida bo'lmoq - to get pregnant", the use of the word "yetilmoq - to come of age" instead of "voyaga yermoq - to grow uo" reflect the linguocultural nature of the Uzbek language. After all, the norms of culture and morality inherent in the Uzbek society have come true, regardless of how they are formed (word or combination) through the euphemism. In summary, the use of euphemisms in speech often depends on the values, norms of etiquette and

американской лингвокультуре:интердискурсивный подход:автореф.дис.канд.филол.наук:/ИГЛУИркутск,2009.20с.

14 Лузина Л.Г. Социальный аспект лингвистических исследований (Обзор)// Социолингвистика вчера и сегодня. -Москва: 2004;Беликов В.И., Крысин Л.П. Социолингвистика.- Москва: 2001.-41с 
CURRENT RESEARCH JOURNAL OF PHILOLOGICAL SCIENCES 2(10): 125-

133, October 2021

DOI: https://doi.org/10.37547/philological-crjps-02-10-23

ISSN 2767-3758

(C2021 Master Journals

Crossref do

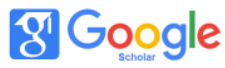

Accepted $26^{\text {th }}$ October, 2021 \& Published $31^{\text {th }}$ October, 2021

social culture established in a particular society by the norms of speech. Euphemisms are a linguistic and socio-cultural phenomenon with a long history in terms of origin. Learning euphemisms eliminates the difficulties, misunderstandings that arise in the process of intercultural communication and ensures that communication is successful and effective.

\section{REFERENCES}

1. Мирзиёев Ш.М. Эркин ва фаровон, демократик Ўзбекистон давлатини биргаликда барпо этамиз. Ўзбекистон Республикаси Президенти лавозимига киришиш тантанали маросимига бағишланган Олий Мажлис палаталарининг қўшма мажлисидаги нутқ. - Тошкент: Ўзбекистон, 2016. Б.13.

2. Ларин Б.А. Об эвфемизмах // Учен. зап. Ленингр. ун-та, № 301: Сер. филол. наук: Вып.№ 60 - Л.: ЛГУ, 1961. - С. 110-124.

3. Крысин Л.П.Эвфемизмы в современной русской речи//www/Philology.ru; Москвин В.П.Эвфемизмы в лексической системе современного русского языка//Василий Павлович Москвин.2е изд.-М.:Лен-д,2007.-264c.; Сеничкина,

4. Е.П.Эвфемизмы русского языка.Москва:Высшая школа,2006.-151с.

5. Кацев А.М.Эвфемизмы в современном английском языке.-Ленинград:Наука, 1977.-65с.//Босчаева

Н.Ц.Контекстуальная эвфемия в современном английском языке.Ленинград:Наука,Ленинградское отд.1989.-130с.//Саакаян Н.Л.Эвфемия как прагмалингвистическая категория в дискурсивной практике непрямого речевого убеждения:автореф.дисс...канд.фил.наук --Москва,2010.-23 с.//Баскова Ю.С.Эвфемизмы как средство манипулирования в языке СМИ(на материале русского и английского языков):дисс...канд.филол.наук.Краснодар,2006.-26с.//Милоенко Е.О.Специфика функционирования эвфемизмов в индивидуальном лексиконе:дисс...канд.фил.наук.Курск,2009.-24 с.

6. Вильданова Г.А. Эвфемия и принцип вежливости в современном английском языке: гендерный аспект. - МоскваБерлин: Директ-Медиа, 2015. -162 с.

7. 7. Баскаков Н.А. Пережитки табу и тотемизма в языках народов Алтая // Советская тюркология. - Баку. 1975. № 2. - C. 3-7.

8. Исматуллаев современном Н.Эвфемизмы в узбекском языке:автореф.дисс.канд.филол.наук.Ташкент,1963-24c//Омонтурдиев А.Эвфемик воситаларнинг функционалуслубий хусусиятлари:филол.фан. номз.дисс.автореф-Т.1997-

23б.//Омонтурдиев А.Профессионал нутқ эвфемикаси(чорвадорлар нутқи мисолида):филол.фан.докт.диссТ.2009-252б.

9. Омонтурдиев А.Омонтурдиев Ж.Сўз қўллаш санъати-Термиз:Жайхун, $199 \backslash 60 б$.

10. Омонтурдиев А.Бир сўз луғатиТермиз:Жайхун,1996-45б.Омонтурдиев A.

11. Ўзбек тилининг қисқача эвфемик луғати-Тошкент,2000134б.Омонтурдиев А.

12. Ўзбек нутқининг эвфемик асослари- 
CURRENT RESEARCH JOURNAL OF PHILOLOGICAL SCIENCES 2(10): 125-

133, October 2021

DOI: https://doi.org/10.37547/philological-crjps-02-10-23

ISSN 2767-3758

(C2021 Master Journals

Crossref do

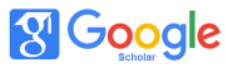

Accepted $26^{\text {th }}$ October, 2021 \& Published $31^{\text {th }}$ October, 2021

Тошкент:Халқ мероси,2000.-128б.

13. Омонтурдиев А.Профессионал нутқ эвфемикаси-Тошкент:Фан, 2006-232б.

14. Маматов А.Ўзбек тили фразеологияси шаклланиши

масалалари:филол.фанлари д-

ри.дисс.автореф-Тошкент,1999-

56б//Холманова

3.“Бобурнома”лексикаси

тадқиқи:филол.фанлари

ри.дисс.автореф-Тошкент,2009- 22 б. //

Қодирова X. Абдулла Қодирийнинг эвфемизм ва дисфемизмлардан фойдаланиш махорати: филол. фан. номз. ... дисс. автореф. - Тошкент, 2009. - 23 б. // Рустамова Д. Метафорик эвфемизациянинг

лингвокультурологик ва социопрагматик аспектлари: филол. фан. номз. ... дисс. автореф. - Фарғона, 2018. - 50 б.

15. Қўнғуров Р., Бегматов Э., Тожиев Э. Нутқ маданияти ва услубият асослари. - Т.: Ўқитувчи, 1992. - 160 б.; Содиқов А., Абдуазизов А., Ирисқулов М. Тилшуносликка кириш. -Т.: Ўқитувчи, 1981. - 266 б.; Mirtojiyev M. O‘zbek tili semasiologiyasi. - Toshkent: Mumtoz so'z, 2010. - 127 b.

16. Шомақсудов А.,Расулов И.,Қўнғуров Р.,Рустамов Х.Ўзбек тили стилистикасиТошкент:Ўқитувчи,1983-

248б.Ш.Гулямова.Ўзбек тили эвфемизмларининг гендер хусусиятлари:филол. фан. номз. ... дисс. автореф. - Бухоро, 2020. - 63 б.

17. Mirtojiyev M.M. O'zbek tili semasiologiyasi. - Toshkent: "Mumtoz so'z, 2010. - B. 119127. . //Маматов А.Э. Ўзбек тили фразеологизмларининг шаклланиши масалалари: Филол. Фанлари д-ри... дисс. - Тошкент, 1999. - Б.156-159. // Шамсиддинов Х. Ўзбек тилида сўзларнинг функционал- семантик синонимлари: Филол.фанлари д-ри... дисс. автореф. - Тошкент, 1999. - 52 б. . // Shamsiddinov H. So'zlarning evfemik funksional-semantik sinonimlari // O‘zbek tili va adabiyoti. -1997.№6.-B.22-25. // Gaybullayeva N.I. The usage of euphemisms in the speech of doctors// International journal of research in humanities, Arts and literature (IMPACT:IJHAL), 2018. - P.525-532. IMPACT Factor. 3.7943. // Ш.Гулямова. Ўзбек тили эвфемизмларининг гендер хусусиятлари. Филология фанлари бўйича фалсафа доктори (PhD) илмий даражасини олиш учун ёзилган диссертация. Бухоро - 2020.1456

18. Usmanova Sh.R.Tarjimaning lingvomadaniy aspektlari.Darslik.-Tosh:2017.-255 b.

19. Пшеничникова А.Б. Гендерные спецификации вежливости в директивных речевых актах в американской лингвокультуре: интердискурсивный подход: автореф. дис.... канд. филол. наук: 10.02.04 / ИГЛУ. - Иркутск, 2009. - 20 с.

20. Лузина Л.Г. Социальный аспект лингвистических исследований (Обзор)// Социолингвистика вчера и сегодня. -Москва: 2004;Беликов В.И., Крысин Л.П. Социолингвистика.Москва: 2001.- 41с

21. L.Raupova. National mental features of compound sentences in the context of a work of art. 2011u. - №1. - P. 39-43.

22. L.Raupova. St. Petersburg, Russia- 
CURRENT RESEARCH JOURNAL OF PHILOLOGICAL SCIENCES 2(10): 125-

133, October 2021

DOI: https://doi.org/10.37547/philological-crjps-02-10-23

ISSN 2767-3758

(C2021 Master Journals

Crossref do

81 Google

Accepted $26^{\text {th }}$ October, 2021 \& Published $31^{\text {th }}$ October, 2021

Hannover, Germany- 2011. - P. 105- 114.

23. L.Raupova.The role of the native language in the process of communication and education $\mathrm{XV} /$ Lazarev readings//Russia,Chelyabinsk-

Chelyabinsk.:2018-P.30-33

24. Шарипова, С., \& Раупова, Л. (2021). XIX asr birinchi yarmi yozma yodgorliklarida adabiy til muammosi. Общество и инновации, 2(4/S), 890-898.

25. Ниязова, Г., \& Раупова, Л. (2021). Detektiv janrning asosiy belgilari va ommabopligi sabablari. Общество и инновации, 2(2/S), 515-524.

26. Ниязова, Г., \& Раупова, Л. (2021). Изучение языка детективных работ в социопрагматических и гендерных аспектах. Общество и инновации, 2(2), 118-125.

27. Шарипова, С., \& Раупова, Л. (2021). Проблема литературного языка в первой половине написанных источников XIX века. Общество и инновации, 2(4/S), 890-898.

28. Raupova, R. L. R., \& Elov, B. B. (2020). THE EXPERIENCE OF BOLOGNA IN REFORMING EDUCATIONAL SYSTEM: THE FORMING OF A CREDIT-MODULE SYSTEM IN THE EDUCATIONAL PROCESS. Solid State Technology, 292-299.

29. Raupova, L. R., \& Kholmurodova, M. I. (2020). ДИАЛОГИЧЕСКИЙ ДИСКУРС КАК СРЕДА, В КОТОРОЙ РЕАЛИЗУЕТСЯ ПОЛИПРЕДИКАТИВНАЯ ЕДИНИЦА. Theoretical \& Applied Science, (3), 451457.

30. Раупова, Л. Р., Сайфуллаева, Р. Р., Хамраева, Х. Х., \& Зарипбоева, Н. М. (2019). Использование лингвистического корпуса в обучении языку. Academy, (8 (47)).

31. Raupova, L., Botirova, A., Musulmanova, N., Kadyrova, H., \& Safarova, G. (2020). Logical and Grammatical Relations in Word Categories: The Factor of Difference and Incarnation. International Journal of Psychosocial Rehabilitation, 24(04).

32. Ниязова, Г., \& Раупова, Л. (2021). Основные признаки и причины популярности детективного жанра. Общество и инновации, 2(2/S), 515-524.

33. Раупова, Л. (2010). ДИАЛОГИК ДИСКУРСДА МИЛЛИЙ МЕНТАЛ ОМИЛЛАРНИНГ НАМОЁН БЎЛИШИ. ВЕСТНИК КАРАКАЛПАКСКОГО ГОСУДАРСТВЕННОГО УНИВЕРСИТЕТА ИМЕНИ БЕРДАХА, 9(3-4), 107-110.

34. Raupova, L., Botirova, A., Musulmanova, N., Kadyrova, H., \& Safarova, G. (2020). Logical and Grammatical Relations in Word Categories: The Factor of Difference and Incarnation. International Journal of Psychosocial Rehabilitation, 24(04).

35. Kudratovna, S. G. (2021). Euphemisms and related events in sociolingÜÍstics. ACADEMICIA: AN INTERNATIONAL MULTIDISCIPLINARY RESEARCH JOURNAL, 11(1), 291-297.

36. Ismatullaeva, N. R. (2020). METHODS OF ELIMINATION OF LEXICAL GAPS IN TRANSLATION (on example of Chinese and Uzbek languages). Scientific Bulletin of Namangan State University, 2(10), 305314. 